\title{
Pengaruh Kualitas Produk dan Promosi Penjualan terhadap Keputusan Pembelian di Starbucks Kuta Bali
}

\author{
Veren1, Ida Ayu Kalpikawati²) \\ 1,2Program Studi Bisnis Hospitality, Politeknik Pariwisata Bali \\ Jl. Dharmawangsa Kampial, Nusa Dua Bali, Telp: (0361) 773537 \\ ${ }^{1}$ verenchang02@gmail.com, ${ }^{2}$ idaayukalpikawati2ppb.ac.id \\ ${ }^{*}$ Penulis Korespondesi
}

\begin{tabular}{l|l|l} 
Received: November, 2020 & Accepted: November, 2020 & Published: December, 2020
\end{tabular}

\begin{abstract}
This research aims to investigate (1) the influence of product quality to the purchase decision, the influence of sales promotion to the purchase and the influence of product quality and sales promotion to the purchase decision at Starbucks Kuta, Bali. The sampling technique used in this research is purposive sampling with the total samples of 86 respondents. Data were collected using questionnaire and documentations and was tested their validity and reliability. The data analysis techniques consist of classic assumption test (normality test, multicollinearity test and heteroscedasticity test), multiple linier regression analysis, $t$ test, $F$ test, determination coefficient test and effective contribution by using SPSS for Mac version 23.0 program. The research results showed that product quality and sales promotion simultaneously had positive and significant influence to the purchase decision. Both variables had an influence of $56,6 \%$ on purchase decision at Starbucks Kuta Bali.
\end{abstract}

Keywords: product quality, sales promotion, purchase decision

\begin{abstract}
Abstrak
Penelitian ini bertujuan untuk mengetahui (1) pengaruh kualitas produk terhadap keputusan pembelian, pengaruh promosi penjualan terhadap pembelian dan pengaruh kualitas produk dan promosi penjualan terhadap keputusan pembelian di Starbucks Kuta Bali. Teknik pengambilan sampel yang digunakan dalam penelitian ini adalah purposive sampling dengan jumlah sampel sebanyak 86 responden. Pengumpulan data menggunakan angket dan dokumentasi serta diuji validitas dan reliabilitasnya. Teknik analisis data terdiri dari uji asumsi klasik (uji normalitas, uji multikolinearitas dan uji heteroskedastisitas), analisis regresi linier berganda, uji t, uji $F$, uji koefisien determinasi dan kontribusi efektif dengan menggunakan program SPSS for Mac versi 23.0. Hasil penelitian menunjukkan bahwa kualitas produk dan promosi penjualan secara simultan berpengaruh positif dan signifikan terhadap keputusan pembelian. Kedua variabel memiliki pengaruh sebesar 56,6\% terhadap keputusan pembelian di Starbucks Kuta Bali.
\end{abstract}

Kata Kunci: kualitas produk, promosi penjualan, keputusan pembelian 


\section{PENDAHULUAN}

Konsep "tempat ketiga" adalah strategi penjualan dari Starbucks untuk menarik pembeli dan menjadikan pembeli tidak hanya sebagai orang yang datang membeli produk lalu pergi begitu saja. Starbucks ingin menjadikan pembeli sebagai teman, rekan dan orang yang dekat. Kedekatan ini bisa dirasakan melalui dekorasi dan suasana yang nyaman dan pilihan menu yang variatif sehingga banyak pelanggan Starbucks yang mampir ke gerai tersebut ketika berangkat dari rumah menuju kantor, atau ketika hendak pulang dari kantor menuju rumah, atau bahkan menjadikan gerai Starbucks sebagai kantornya di mana mereka bisa bertemu dengan orang-orang yang melakukan rapat presentasi dan hal-hal lainnya. Starbucks bukan satu-satunya gerai kopi di Indonesia, namun Starbucks mampu menjadi tempat yang banyak dicari pelanggan di Indonesia bahkan di dunia karena banyak inovasi yang dilakukan. Starbucks di awal tahun 2019 merilis satu gerainya yang luar biasa di Bali. Gerai Starbucks di Bali didirikan sebagai bentuk penghormatan Starbucks terhadap Indonesia yang sejak Starbucks berdiri tahun 1971 telah menggunakan kopi dari Sumatera dan kopi dari tempat-tempat lainnya di Indonesia.

Kotler (2001:22) mengatakan bahwa produk berpengaruh pada keputusan pembelian konsumen. Kotler dan Amstrong (2008) berpendapat semakin baik kualitas produk yang dihasilkan maka akan memberikan kesempatan kepada konsumen untuk melakukan keputusan pembelian. Secara garis besar konsumen Starbucks Kuta Bali merasa puas dari segi kualitas produk yang disajikan, kualitas layanan yang diberikan maupun kenyamanan yang disuguhkan. Pihak Starbucks memiliki bagian customer service yang memiliki tanggung jawab untuk menerima kritik maupun saran yang diberikan oleh konsumen. Melalui kritik dan saran yang diberikan oleh konsumen, pihak manajemen Starbucks berusaha untuk terus meningkatkan pelayanan maupun kualitas produk Starbucks. Buchory dan Saladin (2010) menyatakan "Promotion is the element is an organization's marketing mix that server to inform, persuade, and remind the market of the organization and or its products". Betapapun berkualitasnya suatu produk, bila konsumen belum pernah mendengarnya dan tidak yakin bahwa produk itu tidak akan berguna bagi mereka, maka mereka tidak akan pernah membelinya. Sehingga secara individual variabel promosi berpengaruh terhadap keputusan pembelian.

Starbucks ikut serta dalam menjaga lingkungan dengan menggunakan sedotan berbahan dasar bukan plastik, menjual reusable cup atau mug yang disebut tumbler. Dengan adanya tumbler (mug atau reusable cup) tersebut Starbucks memberikan promosi kepada konsumen yang memiliki tumbler di hari tertentu dengan sebutan "Starbucks Greener Day". Dalam program promosi "Starbucks Greener Day", Starbucks mempromosikan iklan ini di social media seperti Instagram, blast chat pada akun resmi LINE Starbucks Indonesia serta dalam bentuk standing mini baliho. Promosi yang diberikan Starbucks merupakan salah satu bentuk upaya untuk mengajak konsumennya peduli terhadap lingkungan, selain itu hal ini mampu memberikan dampak terhadap keputusan pembelian konsumen.

Pada tahun 2018 Ade Mahayasa menargetkan setidaknya 200 transaksi terjadi setiap "Starbucks Greener Day" dan target ini naik 5\% setiap tahunnya. Tahun 2019 Starbucks Kuta Bali menargetkan minimal 210 transaksi, namun hal ini masih belum mencapai target yang ditentukan. Promosi yang dilakukan sudah sangat jelas dan bahkan tumbler yang dijualpun diletakan di dekat kasir dan pintu masuk Starbucks Kuta Bali. Apabila hal ini terus berlangsung dapat berdampak pada penurunan revenue Starbucks Kuta Bali.

Penelitian ini mengambil lokasi di Starbucks Pantai Kuta Bali Shopping Arcade. Dalam program promosi "Starbucks Greener Day", Starbucks mempromosikan iklan ini di social media seperti Instagram, blast chat pada akun resmi LINE Starbucks Indonesia serta dalam bentuk standing mini baliho. Berdasarkan data jumlah transaksi produk Starbucks 
Kuta Bali setiap tanggal 22 pada tahun 2017-2019 terdapat selisih jumlah transaksi dengan target transaksi. Apabila hal ini terus berlangsung dapat berdampak pada penurunan revenue Starbucks Kuta Bali. Dapat dikatakan bahwa usaha yang dilakukan Starbucks Kuta Bali melalui kualitas produk sudah baik dan promosi juga telah dilakukan, namun tidak disertai dengan peningkatan jumlah transaksi sesuai dengan target yang telah ditentukan di Starbucks Kuta Bali. Maka perlu dilakukan penelitian tentang "Pengaruh Kualitas Produk dan Promosi terhadap Keputusan Pembelian di Starbucks Kuta Bali."

Menurut Kotler dan Armstrong (2018:249) Kualitas produk adalah karakteristik produk atau jasa yang bergantung pada kemampuannya untuk memuaskan kebutuhan konsumen yang dinyatakan maupun tersirat. Menurut David Garvin yang dikutip oleh Fandy Tjiptono (2010:24) mengidentifikasikan adanya lima alternatif perspektif kualitas yang bisa digunakan, yaitu: (1) Transcendental Approach, (2) Product-Based Approach, (3) User-Based Approach, (4) Manufacturing- Based Approach, (5) Value-Based Approach. Kualitas produk dapat dimasukkan ke dalam 5 dimensi sebagai berikut: (1) Presentation (Tampilan), (2) Healthy Options (Menawarkan Produk yang Memperhatikan Kualitas Kesehatan), (3) Taste (Rasa), (4) Freshness (Kesegaran), (5) Temperature (Temperatur).

Promosi adalah penyampaian informasi dari penjual kepada pembeli untuk mempengaruhi sikap-sikap dan tingkah laku dalam rangka menciptakan pertukaran sehingga tujuan untuk meningkatkan kuantitas penjualan diharapkan dapat tercapai. Terdapat enam dimensi promosi penjualan, antara lain (Holbrook, 1994): (1) Monetary savings (penghematan moneter).

(2) Increase in the quality of the product bought (peningkatan kualitas produk yang dibeli). (3) Reduction in searchand decisions cost (pengurangan biaya pencarian dan keputusan). (4) Expression and enhancement of self-concept and personal values (ekspresi dan peningkatan konsep diri dan nilai-nilai pribadi). (5) Simulation and variety (simulasi dan variasi). (6) Amusement and aesthetic value (nilai hiburan danestetika).

Keputusan pembelian menurut Schiffman dan Kanuk (2004:329) adalah pemilihan dari dua atau lebih alternatif pilihan keputusan pembelian yang artinya bahwa seseorang dapat membuat keputusan, haruslah tersedia beberapa alternatif pilihan. Menurut Halim (2015:22) terdapat faktor- faktor yang mempengaruhi keputusan pembelian konsumen, yaitu: (1) Marketing Mix (Bauran Pemasaran), (2) Psychological Factors (Faktor Psikologi), (3) Situational Factors (Faktor Situasional), (4) Social Factors (Faktor Sosial). Dimensi Keputusan Pembelian menurut Dewey (1910): (1)Pengenalan Masalah, (2) Pencarian Informasi, (3) Evaluasi Alternatif, (4) Keputusan Membeli, (5) Perilaku Setelah Membeli.

Berdasarkan latar belakang masalah diatas, maka dapat ditarik rumusan masalah sebagai berikut: (1) Bagaimana pengaruh kualitas produk terhadap keputusan pembelian di Starbucks Kuta Bali? (2) Bagaimana pengaruh promosi terhadap keputusan pembelian di Starbucks Kuta Bali? (3) Bagaimana pengaruh kualitas produk dan promosi terhadap keputusan pembelian di Starbucks Kuta Bali?

Tujuan dari penelitian ini adalah sebagai berikut: (1) Untuk menganalisis pengaruh kualitas produk terhadap keputusan pembelian di Starbucks Kuta Bali. (2) Untuk menganalisis pengaruh promosi terhadap keputusan pembelian di Starbucks Kuta Bali. (3) Untuk menganalisis pengaruh kualitas produk dan promosi terhadap keputusan pembelian di Starbucks Kuta Bali.

\section{METODE PENELITIAN}

Data dalam penelitian ini diperoleh dari hasil kuesioner melalui google form yang diberikan kepada 80 orang yang pernah membeli produk Starbucks di Starbucks Kuta Bali. Data juga diperoleh melalui dokumentasi dari pihak Starbucks Kuta Bali berupa jumlah transaksi di tahun 2017-2019. Selain itu juga adapun data yang diunggah dari Trip 
Advisor Starbucks Kuta Bali. Teknik analisis yang digunakan adalah uji validitas, uji reliabilitas, uji asumsi klasik (uji normalitas, uji multikolinearitas, uji heteroskedastisitas), analisis regresi linier berganda, uji t, uji F, uji koefisien determinasi dan sumbangan efektif dengan menggunakan program SPSS (Statistic Product and Service Solution) for Mac version 23.0.

Kuesioner merupakan instrumen penelitian yang mengukur variabel penelitian, yakni terdiri dari variabel usia, dengan rentang $<20$ tahun, 21-30 tahun, 31-40 tahun, 4150 tahun dan $>50$ tahun, jenis kelamin terdiri dari pria dan wanita, dan pendidikan terakhir terdiri dari SMA/SMK, diploma, sarjana dan lainnya.

Penelitian ini memiliki 2 variabel independen (variabel bebas) yaitu Kualitas Produk (X1) dan Promosi (X2) terhadap variabel dependen (variabel terikat) yaitu Keputusan Pembelian (Y). Kualitas Produk sebagai variabel independen (X1) yang diukur melalui indikator tampilan, menawarkan pilihan sehat, rasa, kesegaran, temperatur. Promosi sebagai independen (X2) yang diukur melalui indikator monetary savings, increase in the quality of product bought, reduction in search and decision costs, expression and enhance of self-concept and personal values, stimulation and variety, amusement and aesthetic value. Keputusan membeli (purchase decision) sebagai variabel dependen atau variabel yang mempengaruhi variabel independen yang diukur dengan indikator pengenalan masalah, pencarian informasi, evaluasi alternatif, keputusan membeli, perilaku setelah membeli. Berikut merupakan kerangka pemikiran yang menjadi dasar dari penelitian ini:

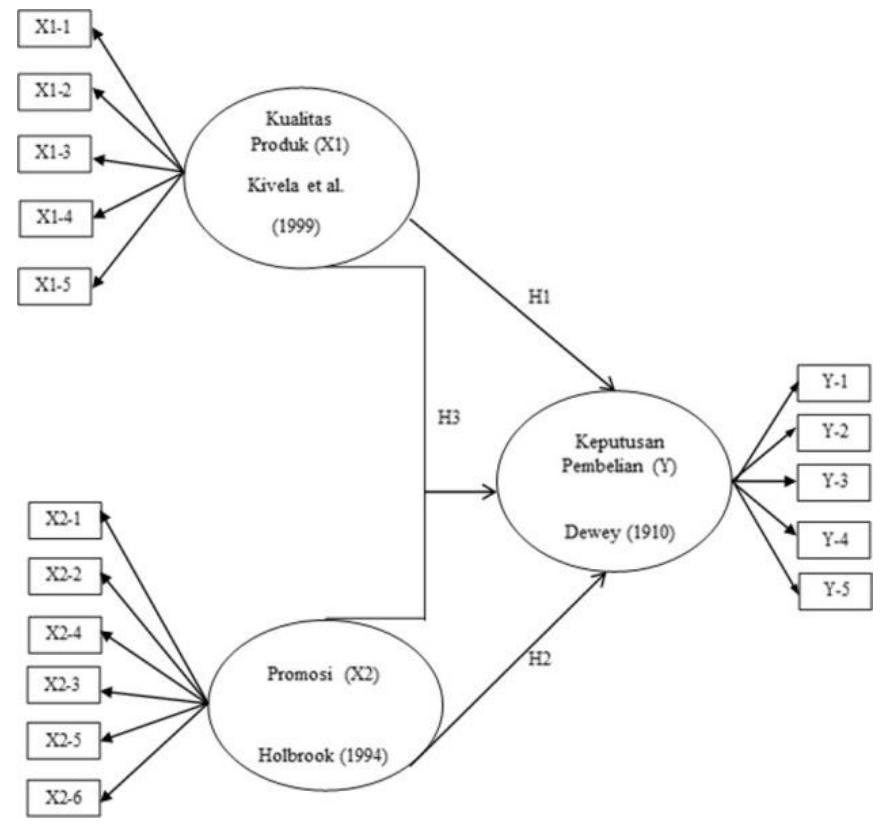

Gambar 1. Kerangka Berpikir berikut:

Berdasarkan kerangka berpikir pada Gambar 1, dapat ditarik hipotesis sebagai

Ho1: Tidak terdapat pengaruh antara Kualitas Produk terhadap Keputusan Pembelian pada konsumen Starbucks KutaBali.

Ha1: Terdapat pengaruh antara Kualitas Produk terhadap Keputusan Pembelian pada konsumen Starbucks Kuta Bali.

Ho2: Tidak terdapat pengaruh antara Promosi Penjualan terhadap Keputusan Pembelian pada konsumen Starbucks KutaBali. 
Ha2: Terdapat pengaruh antara Promosi Penjualan terhadap Keputusan Pembelian pada konsumen Starbucks Kuta Bali.

Ho3: Tidak terdapat pengaruh antara Kualitas Produk dan Promosi Penjualan terhadap Keputusan Pembelian pada konsumen Starbucks Kuta Bali.

Ha3: Terdapat pengaruh antara Kualitas Produk dan Promosi Penjualan terhadap Keputusan Pembelian pada konsumen Starbucks Kuta Bali.

\section{HASIL DAN PEMBAHASAN}

Dari hasil penelitian dengan total 86 responden, dapat diketahui gambaran tentang karakteristik responden dimana pada penelitian ini usia responden didominasi oleh rentang usia 21-30 tahun, yaitu sebanyak 63 orang (73,3\%), dengan rentang usia 31-40 tahun sebanyak 16 orang $(18,6 \%)$, rentang usia $<20$ tahun sebanyak 7 orang $(8,1 \%)$. Jenis kelamin responden didominasi oleh laki-laki, yaitu sebanyak 47 orang $(54,7 \%)$, dengan perempuan sebanyak 39 orang (45,3\%). Pendidikan terakhir responden didominasi oleh sarjana, yaitu sebanyak 41 orang $(47,7 \%)$. Disusul dengan SMA/SMK sebanyak 35 orang $(40,3 \%)$, diploma sebanyak 7 orang $(8,1 \%)$ dan lainnya sebanyak 3 orang $(3,5 \%)$.

Hasil uji validitas variabel kualitas produk, promosi penjualan, keputusan pembelian secara keseluruhan dinyatakan valid karena angka rhitung $>$ dari rtabel yaitu 0,212 . Hasil uji reliabilitas, instrumen dikatakan reliabel apabila $r$ hitung $>r$ tabel dengan taraf signifikansi 5\%, variabel kualitas produk, promosi penjualan dan keputusan pembelian secara keseluruhan dinyatakan reliabel menunjukkan angka rhitung $>$ dari $\mathrm{r}$ tabel yaitu 0,212 .

Teknik analisis data yang digunakan untuk menguji hipotesis adalah uji asumsi klasik terdiri dari uji normalitas, uji multikolinearitas dan uji heterokedastisitas, regresi linier berganda, uji t, uji F, koefisien determinasi dan sumbangan efektif.

\subsection{Pengaruh Kualitas Produk terhadap Keputusan Pembelian}

Hasil pengujian hipotesis diperoleh hasil thitung $>$ ttabel $=2,566>1,98896$ dan nilai signifikansi $<\alpha=0,012<0,05$. Hal ini menunjukkan bahwa kualitas produk berpengaruh positif dan signifikan terhadap keputusan pembelian di Starbucks Kuta Bali. Melalui uji sumbangan efektif yang telah dilakukan, didapatkan hasil sebesar 19,0518\% yang menunjukkan besar pengaruh kualitas produk terhadap keputusan pembelian.

\subsection{Pengaruh Promosi Penjualan terhadap Keputusan Pembelian}

Hasil pengujian hipotesis Diperoleh hasil thitung $>$ ttabel $=4,779>1,98896$ dan nilai signifikansi $<\alpha=0,000<0,05$. Hal ini menunjukkan bahwa promosi penjualan berpengaruh positif dan signifikan terhadap keputusan pembelian di Starbucks Kuta Bali. Melalui uji sumbangan efektif yang telah dilakukan, didapatkan hasil sebesar 38,4928\% yang menunjukkan besar pengaruh promosi penjualan terhadap keputusan pembelian.

\subsection{Pengaruh Kualitas Produk dan Promosi Penjualan terhadap KeputusanPembelian}

Hasil pengujian hipotesis diperoleh hasil bahwa variabel kualitas produk dan promosi penjualan berpengaruh positif dan signifikan secara simultan terhadap variabel keputusan pembelian dengan persamaan regresi linier berganda yaitu keputusan pembelian $\mathrm{Y}=4,870+0,272 \mathrm{X} 1+0,513 \mathrm{X} 2+2,169$ artinya bahwa jika meningkatnya kualitas produk serta promosi penjualan, maka akan terjadi peningkatan pada keputusan pembelian. Dari hasil tersebut dapat disimpulkan juga bahwa promosi penjualan dapat lebih besar memberikan pengaruh untuk meningkatkan keputusan pembelian dibandingkan dengan kualitas produk. 
Hasil uji $\mathrm{F}$ menunjukkan secara simultan kualitas produk dan promosi penjualan berpengaruh signifikan terhadap keputusan pembelian dilihat dari nilai Fhitung $>$ Ftabel $=$ $56,350>3,11$ dan nilai signifikansi $<\alpha=0,000<0,05$. Dilihat dari hasil uji koefisien determinasi menunjukkan bahwa kualitas produk dan promosi penjualan secara bersamasama berkontribusi sebesar $56,6 \%$ terhadap keputusan pembelian, sedangkan sisanya $43,4 \%$ dipengaruhi oleh faktor lain yang tidak diteliti dalam penelitian ini.

\subsection{Pembahasan}

Variabel kualitas produk (X1) secara parsial berpengaruh positif dan signifikan terhadap keputusan pembelian (Y) di Starbucks Kuta Bali ditunjukkan dengan nilai signifikansi 0,012<0,05, nilai t-hitung 2,566 > t-tabel 1,98896 dan nilai koefisien regresi sebesar 0,272. Hasil dari sumbangan efektif menunjukkan kualitas produk secara parsial memiliki kontribusi sebesar 19,0518\%.

Variabel promosi penjualan (X2) secara parsial berpengaruh positif dan signifikan terhadap Keputusan Pembelian (Y) di Starbucks Kuta Bali ditunjukkan dengan nilai signifikansi $0,000<0,05$, nilai t-hitung 4,779 > t-tabel 1,98896 dan nilai koefisien regresi sebesar 0,513. Hasil dari sumbangan efektif menunjukkan promosi penjualan secara parsial memiliki kontribusi sebesar 38,4928\%.

Variabel kualitas produk (X1) dan promosi penjualan (X2) secara simultan berpengaruh positif dan signifikan terhadap Keputusan Pembelian di Starbucks Kuta Bali dengan nilai Fhitung 56,350 > Ftabel 3,10 dan berdasarkan analisis koefisien determinasi memiliki pengaruh sebesar 0,566 atau 56,6\% sedangkan sisanya 43,4\% dipengaruhi oleh variabel lain diluar penelitian. Hasil dari sumbangan efektif menunjukkan kualitas produk secara parsial memiliki kontribusi sebesar 19,0518 \% dan promosi penjualan secara parsial memiliki kontribusi sebesar 38,4928\%.

\section{KESIMPULAN}

Berdasarkan hasil penelitian yang telah dilakukan, maka dapat disimpulkan sebagai berikut: (1) Variabel kualitas produk (X1) secara parsial berpengaruh positif dan signifikan terhadap keputusan pembelian (Y) di Starbucks Kuta Bali. Hal ini mengindikasikan bahwa apabila kualitas produk mengalami peningkatan, maka keputusan pembelian juga meningkat. (2) Variabel promosi penjualan (X2) secara parsial berpengaruh positif dan signifikan terhadap Keputusan Pembelian (Y) di Starbucks Kuta Bali. Hal ini mengindikasikan bahwa apabila promosi penjualan mengalami peningkatan, maka keputusan pembelian juga meningkat. (3) Variabel kualitas produk (X1) dan promosi penjualan (X2) secara simultan berpengaruh positif dan signifikan terhadap Keputusan Pembelian di Starbucks Kuta Bali.

Berdasarkan simpulan, maka saran yang dapat diberikan kepada pihak terkait dengan penelitian ini mengenai pengaruh Kualitas Produk dan Promosi Penjualan terhadap Keputusan Pembelian adalah sebagai berikut:

1) Mengacu pada nilai rata-rata jawaban responden mengenai kualitas produk. Pernyataan kedua, yaitu terkait healthy option memiliki nilai rata-rata terendah $(4,69)$ diantara item pernyataan lainnya mengenai kualitas produk. Oleh sebab itu, Starbucks sebaiknya menawarkan produk yang lebih memperhatikan kualitas kesehatan produk tersebut. Kualitas kesehatan produk yang dimaksud dapat berupa penambahan variasi menu sehat kepada konsumen.

2) Mengacu pada nilai rata-rata jawaban responden mengenai promosi penjualan. Pernyataan kesembilan, yaitu terkait value expression memiliki nilai rata-rata terendah $(4,52)$ diantara item pernyataan lainnya mengenai promosi penjualan. Oleh karena itu pihak manajemen Starbucks Kuta Bali harus terus berinovasi dalam menggunakan strategi promosi yang efektif, seperti promosi dengan metode pembayaran dengan 
uang elektronik seperti OVO, Shopeepay, DANA, Gopay dengan maksud untuk meningkatkankeputusan pembelian produk Starbucks Kuta Bali.

3) Mengacu pada nilai rata-rata jawaban responden mengenai keputusan pembelian. Pernyataan terkait evaluation alternatives memiliki nilai rata-rata terendah $(4,69)$ diantara item pernyataan lainnya mengenai keputusan pembelian. Oleh sebab itu, pihak manajemen Starbucks Kuta Bali harus mempertahankan kualitas produk dan menambah jenis promosi seperti menawarkan alternatif pembayaran menggunakan pembayaran elektronik yang memberikan cashback guna untuk meningkatkan keputusan pembelian produk Starbucks Kuta Bali.

4) Pada penelitian ini, untuk total sampel yang diambil didapatkan dari total indikator variabel dikalikan dengan 5 yaitu tingkat yang lebih kecil karena kondisi Indonesia yang sedang terkena pandemi Covid-19. Oleh karena itu, apabila situasi sudah membaik,untuk penelitian selanjutnya dapat mengalikan dengan 10 untuk mendapatkan total sampel yang lebih banyak, agar hasil penelitian lebih maksimal.

\section{DAFTAR PUSTAKA}

Buchory, H. A., \& Saladin, D. (2010). Manajemen Pemasaran: Teori, Aplikasi \&Tanya Jawab. Jakarta: Linda Karya.

Halim. (2015). Auditing: Dasar-dasar Audit Laporan Keuangan (5th ed.). Yogyakarta: UPP STIM YKPN.

Kotler, P. (2001). Manajemen Pemasaran: Analisis, Perencanaan, Implementasi, dan Kontrol. Jakarta: PT. Prehallindo.

Kotler, P., \& Amstrong, G. (2018). Principles of Marketing (17th ed.). USA: Pearson Education.

Schiffman \& Kanuk. (2004). Consumer behaviour (7th ed.). New Jersey: Prentice Hall. 